https://journal.unram.ac.id/index.php/jmai/index. E-ISSN : 2798-0553

VOLUME 1, NOMOR 1, JUNI 2021

\title{
PENGARUH SISTEM RESIRKULASI TERHADAP KUALITAS AIR DAN KELULUSAN HIDUP IKAN BANGGAI CARDINAL (Pterapogon kauderni)
}

\author{
EFFECT OF RECIRCULATION SYSTEM ON WATER QUALITY AND SURVIVAL RATE OF \\ CARDINAL BANGGAI FISH (Pterapogon kauderni)
}

Jacqueline M.F. Sahetapy, Absalom Luturmas, Muhamad Renaldy Kiat

Jurusan Budidaya Perairan, Fakultas Perikanan dan Ilmu Kelautan Universitas Pattimura

Jalan Mr.Chr Sopanit Kampus Poka Ambon ,Provinsi Maluku 97233

Alamat Korespondensi : jmf_sahetapy@yahoo.com

\begin{abstract}
ABSTRAK
Sistem Resirkulasi merupakan suatu metode pemeliharaan ikan dalam wadah terkontrol dalam menggunakan kembali air bekas setelah proses penyaringan secara fisik dan biologi. Salah satu bentuk sistem resirkulasi yaitu multi layer filter. Penelitian ini bertujuan untuk mengetahui parameter kualtas air dan tingkat kelangsungan hidup pada pemeliharaan ikan banggai cardinal $(P$. kauderni) dengan menggunakan variasi sistem resirkulasi multi layer filter. Kegiatan Penelitian ini dilaksanakan selama 1 bulan dari bulan februari - maret 2019 di Laboratorium Unit Kultivasi Program Studi Budidaya Perairan-Universitas Pattimura Ambon. Penelitian ini menggunakan desain wadah resirkulasi dengan 2 perlakuan sistem dan media filter yang digunakan yaitu dakron, arang aktif, pasir pantai, bioball, dan keramik mika. Data yang diperoleh kemudian dianalisa menggunakan analisis deskriptif, kemudian data tersebut diolah pada Microsoft office Excel 2010, disajikan dalam bentuk tabel dan grafik. Hasil penelitian ini menunjukan bahwa hasil pengukuran konsentrasi amonia yang diperoleh bahwa pada perlakuan B (Bioball, arang aktif, dakron, dan pasir) dapat mereduksi amonia lebih optimal dengan nilai konsentrasi di minggu terakhir yaitu 0.3 mg/l dan perlakuan ini dapat menjaga kelangsungan hidup ikan banggai cardinal berkisar $66.67 \%$ lebih baik dibandingkan perlakuan yang lainnya. Dapat disimpulkan bahwa variasi komponen sistem resirkulasi multi layer filter pada perlakuan dengan kombinasi filter bioball, arang aktif, dakron dan pasir mampu mereduksi amonia, serta memberikan pengaruh yang lebih baik terhadap kualitas air sehingga mampu meningkatkan kelangsungan hidup ikan banggai cardinal.
\end{abstract}

Kata Kunci Resirkulasi, Kelulusan hidup, ikan banggai cardinal

Tracebility Tanggal diterima : 21 Mei 2021. Tanggal publikasi : 23 Juni 2021

Panduan Sahetapy, J.M.F., Luturmas, A., \& Kiat, M.R. (2021). Pengaruh Sistem Resirkulasi

Kutipan Terhadap Kualitas Air dan Kelulusan Hidup Ikan Banggai Cardinal (Pterapogon

(APPA $7^{\text {th) }}$ kauderni). Jurnal Media Akuakultur Indonesia, 1 (1), 1-10. http://doi.org/10.29303/mediaakuakultur.v1i1.119 


\section{PENDAHULUAN}

Ikan Banggai Cardinal yang memiliki nama ilmiah Pterapogon kauderni merupakan ikan laut endemik di Kepulauan Banggai, Provinsi Sulawesi Tengah, dan tidak ditemukan di tempat lain di dunia. Masyarakat setempat menyebutnya "capungan" atau "bibisan". Namun dengan maraknya perdagangan ikan hias dengan harga yang cukup menggiurkan, maka ikan tersebut juga dapat ditemukan ditempat lain terutama di pulau Bali (tepatnya disekitar perairan Gilimanuk). Kualitas media atau lingkungan pemeliharaan yang optimal/layak merupakan faktor-faktor penting dalam pengembangan pengelolaan dan dalam budidaya spesies tersebut.Untuk mempertahakan kualitas media budidaya yang baik pada pemeliharaan ikan hias biasanya digunakan sistem resirkulasi agar kualitas airnya dapat terjaga dengan baik dalam kegiatan budidaya.Sistem resirkulasi merupakan sistem yang memanfaatkan kembali air yang sudah digunakan dengan cara memutar air secara terus-menerus melalui perantara sebuah filter di dalam wadah (Fauzzia $d k k$., 2013) sehingga sistem ini bersifat hemat air (sidik, 2002; Djokosetiyanto $d k k$, 2006; Prayogo $d k k$ 2012), oleh karena itu sistem ini merupakan salah satu alternatif modal budidaya yang memanfaatkan air secara berulang dan berguna untuk menjaga kualitas air (Djokosetiyanto $d k k, 2006$ ). Sistem resirkulasi ada 2 jenis yakni sistem resirkulasi tertutup yang mendaur ulang 100\% air dan sistem resirkulasi semi tertutup yang mendaur ulang sebagian air sehingga masih membutuhkan penambahan air dari luar (Sidik, 2002).

Beberapa bentuk sistem resirkulasi sederhana ialah double bottom filter atau serkarang diperbaruhi menjadi multi layer filter/komponen filter yang lebih dari dua lapisan filter. Filter ini umumnya merupakan saringan dari seng plastik bergelombang atau kawat halus. Saringan ini menyebabkan adanya ruangan antara filter dan dasar akuarium untuk air bersih. Dengan menggunakan material seperti pasir, kerikil, dakron, bioball, dan arang aktif yang akan mengikat kandungan zat-zat yang bersifat toksik bagi biota yang ada di dalamnya.

Berdasarkan hasil penelitian yang telah dilakukan oleh Sahetapy $d k k$ (2016), menemukan bahwa pada pemelihararaan ikan Blue Devil (Chrysiptera cyanea) sistem resirkulasi double bottom filter dengan komposisi dakron dan pasir mampu mereduksi amonia dan meningkatkan kelangsungan hidup 90\%.dibandingkan dengan komposisi yang lain. Dirasa perlu melakukan modifikasi komponen filter pada sistem resirkulasi untuk itu penelitian ini dilakukan dengan tujuan untukmengetahui parameter kualtas air dan tingkat kelulusan hidup pada pemeliharaan ikan banggai (P. kauderni) dengan menggunakan variasi sistem resirkulasi multi layer filter. 


\section{METODE PENELITIAN}

\section{Waktu dan tempat Penelitian}

Kegiatan Penelitian ini dilaksanakan dari bulan Januari - maret 2019 bertempat di Laboratorium Unit Kultivasi Program Studi Budidaya Perairan-Universitas Pattimura Ambon.

\section{Rancangan Penelitian}

Penelitian ini menggunakan Rancangan Acak Lengkap (RAL) dengan menggunakan 2 perlakuan dan 3 kali ulangan. Perlakuan variasi filter dalam sistem resirkulasi yang adalah sebagai berikut

Perlakuan A : Tanpa Filter biologis hanya Arang aktif, dakron dan pasir (Kontrol)

Perlakuan B : Variasi filter berupa Bio ring, arang aktif, dakron dan pasir (Gambar 1)

Perlakuan C : Variasi filter berupa Bioball, arang atif, dakron dan pasir

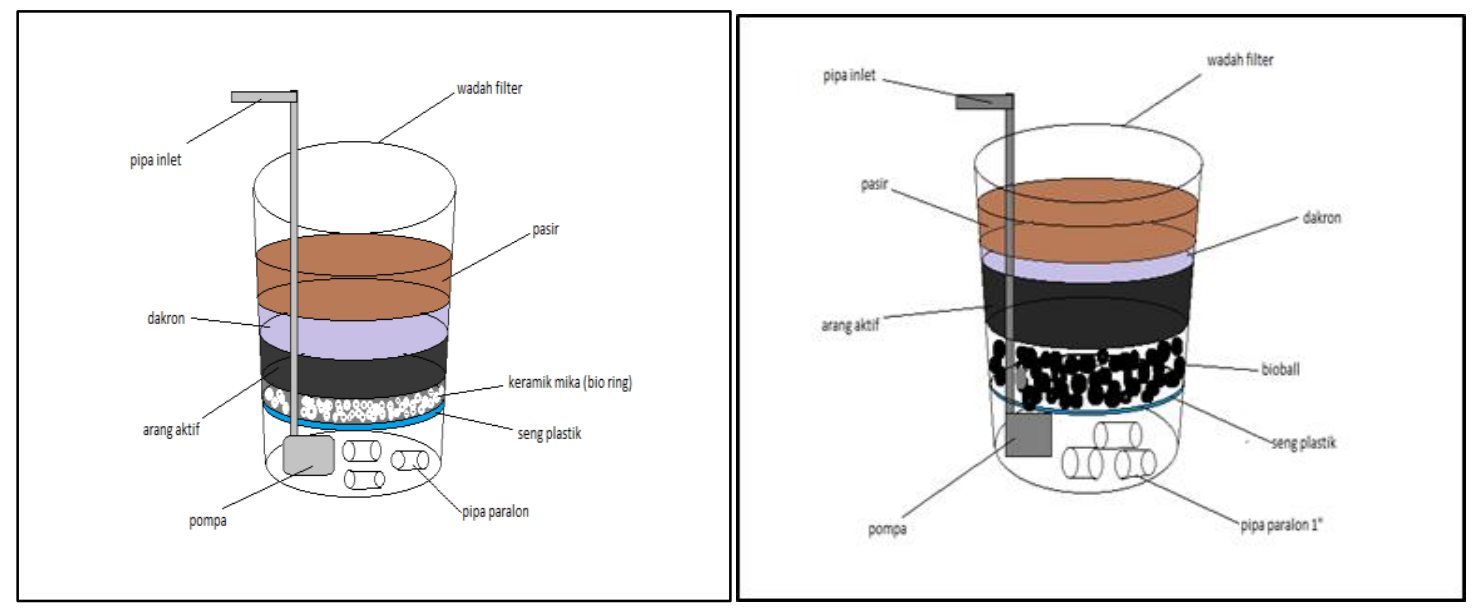

Gambar 1. Variasi komponen filter pada sistem resirkulasi untuk perlakuan B dan C

\section{Bahan dan Alat}

Bahan yang digunakan dalam penelitian ini adalah benih ikan Banggai Cardinal, Air laut, Air tawar, Dakron, arang aktif, bioball, bio ring (keramik mika). Alat-alat yang digunakan adalah Akuarium, ember, pipa paralon, seng plastik, selang aerasi, pompa celup, termometer, refraktometer, DO meter, timbangan digital dan alat tulis.

\section{Prosedur Penelitian}

\section{Persiapan Wadah}

Wadah penelitian yang digunakan adalah akuarium berukuran 30x30x30 cm sebanyak 9 buah kemudian dilanjutkan dengan perangkaian sistem resirkulasi dan penyusunan komponen media filter dalam wadahnya. 


\section{Persiapan Ikan Uji}

Ikan Banggai Cardinal (P. kauderni) (Gambar 2) diperoleh dari Balai Perikanan Budidaya Laut Ambon dan yang digunakan sebanyak 180 individu, dimana berisi 20 individu pada setiap akuarium yang berjumlah 9 wadah pemeliharaan.Ikan diadaptasikan dengan wadah selama 1 minggu sampai kondisinya stabil dan siap untuk digunakan dalam penelitian.

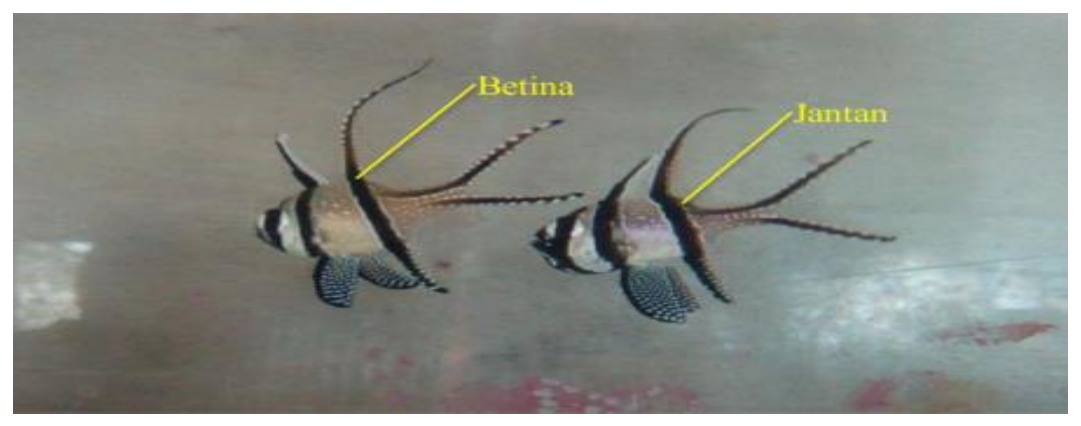

Gambar 2. Ikan Banggai Cardinal (P. kauderni)

\section{Pemeliharaan}

Masa Pemeliharaan selama 1 bulan setelah sebelumnya dilakukan aklimatisasi selama 1 minggu. Ikan diberi pakan berupa pakan pellet otohime yang diberikan selama 4 mingg dengan frekuensi 2 kali sehari secara ad satiation.

\section{Parameter Yang diamati}

Parameter yang diamati adalah konsentrasi amonia, kelulusan hidup serta parameter kualitas air (Suhu, salinitas, pH dan Oksigen terlarut ). Konsentrasi amonia dianalisa di laboratorium kesehatan Ambon

Kelulusan Hidup (Survival Rate)

Perhitungan Kelangsungan Hidup ikan menggunakan rumus menurut (Effendie, 1997) :

$\mathrm{SR}=\mathrm{Nt}_{\mathrm{x}} \mathbf{1 0 0}$

No

Keterangan :

SR $=$ Tingkat Kelangsungan Hidup (\%)

$\mathrm{Nt}=$ Jumlah ikan hidup pada akhir pemeliharaan (ekor)

No $=$ Jumlah ikan pada awal pemeliharaan (ekor)

\section{Analisis Data}

Data konsentrasi amonia dan tingkat kelulusan hidup Ikan Banggai Cardinal $(P$. kauderni) yang diperoleh kemudian dianalisa menggunakana analisis deskriptif, kemudian data-data tersebut diolah pada Microsoft office Excel 2010, disajikan dalam bentuk tabel dan grafik. 


\section{HASIL DAN PEMBAHASAN}

\section{Amonia}

Amonia merupakan produk akhir utama penguraian protein pada ikan. Ikan akan mencerna protein dalam pakan dan mengekskresikan amonia melalui insang dan feses. Amonia pada lingkungan budidaya juga berasal dari proses dekomposisi bahan organik seperti sisa pakan, alga mati dan tumbuhan akuatik (Duborow et al., 1997). Hasil penelitian menunjukkan bahwa Pengukuran konsentrasi amonia dilakukan secara menyeluruh pada masing-masing perlakuan dengan 3 kali pengukuran dalam satu bulan antara minggu awal, tengah, dan akhir dimana setiap perlakuan menggunakan variasi multi layer filter yang berbeda, dari hasil pengukuran dapat menunjukan bahwa perlakuan C (Bio ring, arang aktif, dakron, dan pasir) dapat mereduksi amoniak dengan baik yaitu dengan kisaran antara minggu awal $0.3 \mathrm{mg} / \mathrm{l}$, kemudian minggu kedua $0.9 \mathrm{mg} / \mathrm{l}$ dan pada minggu terakhir mendapatkan hasil $0.2 \mathrm{mg} / \mathrm{l}$. Sedangkan pada hasil pengukuran konsentrasi amoniak pada perlakuan B (bioball, arang aktif, dakron, dan pasir) berkisar antara minggu awal $0.3 \mathrm{mg} / \mathrm{l}$, minggu kedua $0.6 \mathrm{mg} / \mathrm{l}$, dan pada minggu terakhir mendapatkan hasil 0.3 mg/l. Kemudian pada perlakuan A (kontrol) mendapatkan hasil berkiar antara minggu awal $0.4 \mathrm{mg} / \mathrm{l}$, minggu kedua $0.5 \mathrm{mg} / \mathrm{l}$, dan minggu terakhir yaitu $0.4 \mathrm{mg} / \mathrm{l}$ (Gambar 3).

Dari hasil pengukuran konsentrasi amonia dengan adanya variasi komponen multi layer filter, dapat dijelaskan bahwa pada perlakuan C memiliki hasil konsentrasi amonia paling rendah pada minggu terakhir tetapi ini bukan penentu bahwa perlakuan $\mathrm{C}$ dapat mereduksi amonia dengan optimal, ini dikarenakan pada pengukuran konsentrasi amonia di minggu kedua hasil konsentrasi yang didapat sangatlah tinggi dengan jumlah kematian yang meningkat. Hal ini dapat diindikasikan bahwa hasil pengukuran konsentrasi amonia pada minggu terakhir mendapatkan nilai yang rendah dikarenakan jumlah ikan yang sudah sangat berkurang dari jumlah sebelumnya karena kematian dan pada pemberian pakan yang diberikan sangatlah sedikit dan membuat kurangnya sisa produk metabolisme dan sisa pakan yang menumpuk pada wadah pemeliharaan. Sedangkan untuk perlakuan A dan B memiliki nilai konsentrasi amonia yang berbeda-beda dan hasil menunjukan bahwa pada perlakuan B dapat mereduksi amonia hingga konsentrasinya menjadi $0.3 \mathrm{mg} / \mathrm{l}$ dan pada pelakuan ini dapat menjaga sintasan pemeliharaan Ikan Banggai Cardinal lebih baik dari pada perlakuan A dan C. Artinya dapat dijelaskan bahwa penyerapan kandungan amonia lebih baik ada pada perlakuan filtrasi yang menggunakan bioball yakni perlakuan B dengan variasi filter sebagai berikut yaitu bioball pada bagian dasar, kemudia lapisan selanjutnya arang aktif, dakron, dan pasir pada lapisan terakhir atau paling atas. 


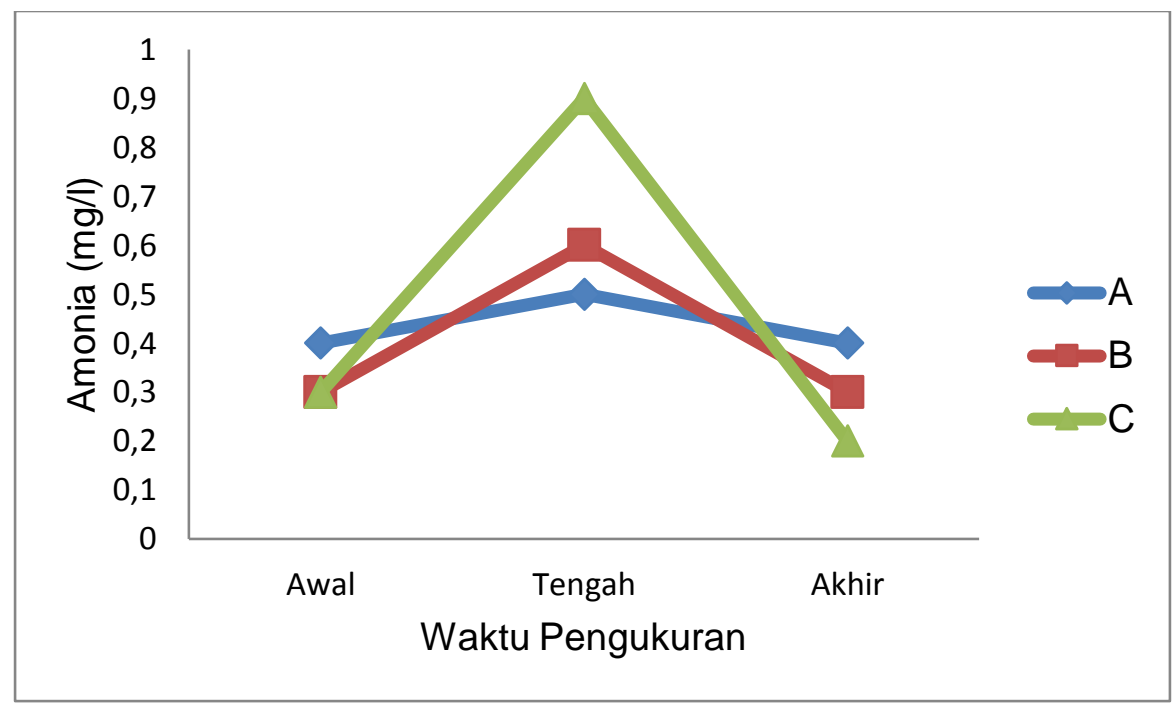

Gambar 3. Konsentrasi amonia selama penelitian

Terdapat 2 bentuk amonia di air, yaitu yang terionisasi (amonium, NH4+ ) dan yang tidak terionisasi (amonia, NH3). Amonia yang tidak terionisasi berbahaya bagi organisme akuatik, karena bersifat toksik (Masser et al., 1999).Nilai NH3 tergantung pada nilai pH dan suhu perairan.Semakin tinggi suhu dan $\mathrm{pH}$ air, persentase NH3 semakin tinggi (Boyd, 1990).

Konsentrasi amonia yang tinggi di dalam air akan mempengaruhi permeabilitas ikan oleh air dan mengurangi konsentrasi ion di dalam tubuh. Amonia juga meningkatkan konsumsi oksigen di jaringan, merusak insang, dan mengurangi kemampuan darah untuk mengangkut oksigen (Boyd, 1982). Kadar amonia bebas yang tidak terionisasi (NH3) pada media air sebaiknya tidak lebih dari $1 \mathrm{mg} / \mathrm{l}$.

Bioball merupakan salah satu media filter biologi yang sistem kerjanya menggunakan mikroorganisme/bakteri yang bekerja secara simultan yaitu bukan hanya berperan sebagai penyaring melainkan sebagai media atau tempat hidup bagi mikroorganisme/bakteri (O-Fish, 2012). Menurut Cahyo (2011) Bioball merupakan penyerap amonia yang sangat efisien dan juga menyediakan ruangan untuk nitrifikasi dalam sistem resirkulasi.Intinya bahwa bioball berfungsi untuk mengurangi amonia dan nitrogen dengan bantuan nitrobacter sehingga bioball mampu menyaring partikel-partikel kecil yang larut dalam air.Sedangkan pada variasi filter yang lain pada desain perlakuan B juga membantu mereduksi amonia sesuai dengan fungsinya masing-masing. Contohnya penggunaan arang aktif / karbon aktif yang berfungsi untuk menyerap zat racun yang ada dalam air atau memisahkan kandungan amonia yang ada dalam air dengan cara menyerap zat toksik tersebut. Zat racun tersebut akan terperangkap pada pori-pori arang kemudian pori-pori arang akan menyerap zat tersebut hingga jumlah zat racun akan berkurang (Ristiana dkk, 2009). Arang aktif bekerja secara absorbs atau penyerapan yang artinya pada saat ada bahan yang melalui arang aktif maka material yang terkandung dalam zat 
tersebut akan diserap. Maka arang aktif ini mampu mengambil beberapa kandungan tidak baik dari air yang telah tercemar dengan fungsi sekaligus untuk menjernihkan air, menghilangkan bau dari air, menyerap kaporit atau chlorine pada air, dan menciptakan rasa segar pada air.

Adapun variasi filter yang lain seperti dakron / polietilena memiliki pori-pori yang sangat kecil dan padat ini dikarenakan bahan pembuatan dakron terbuat dari serat sintesis. Dakron memiliki fungsi untuk menyaring partikel-partikel yang larut dalam air. Kelebihan dari dakron yaitu dikenal sebagai saringan atau filter untuk akuarium, bahannya tidak cepat rusak, dan mudah dicuci. Kemudian ada variasi filter terakhir yang digunakan dalam penelitian ini yaitu pasir. Pasir merupakan media filter yang sering digunakan dalam media air budidaya. Pasir berfungsi sebagai filter air karena pasir sangat efektif dalam menjernihkan air yang keruh oleh substansi yang terlarut dalam air, menyaring lumpur, endapan, serta partikel asing lainnya, sehingga pasir mampu membantu mengurangi kadar amonia yang ada di dalam air.

Dari beberapa variasi filter yang digunakan memiliki fungsinya masing-masing tetapi dapat membantu dalam mereduksi konsentrasi amonia. Keberadaan amonia dengan konsentrasi yang tinggi dalam air dapat mempengaruhi pertumbuhan ikan dan dapat menyebabkan kematian pada ikan yang dipelihara. Kisaran amonia yang diperoleh selama penelitian untuk masing-masing perlakuan berksiar antara 0.2-0.9 mg/l, ini menunjukan bahwa variasi komponen sistem resirkulasi multi layer filter terbukti cukup efektif untuk mereduksi limbah nitrogen dalam hal ini adalah amonia dan hasil yang didapatkan menunjukan bahwa pada perlakuan B dapat mereduksi amonia dengan hasil yang masih dalam kisaran yang layak untuk pertumbuhan dan kelangsungan hidup ikan uji. Menurut Kordi (2004), media air yang baik untuk budidaya ikan adalah yang mengandung amonia kurang dari 1 ppm.

\section{Parameter Kualitas Air}

Paramater kualitas air selama periode pemeliharaan dapat dilihat pada tabel 1 di bawah ini. Terlihat bahwa parameter kualitas air baik suhu, salinitas, $\mathrm{pH}$ dan DO memperlihatkan nilai yang masih dalam batas optimal untuk kehidupan ikan banggai cardinal di akuarium. Nilai kisaran suhu 27,8-29ํㅡ, salinitas 33-35 ppt, pH 7,5-7,9 dan DO 4,9-6,2 mg/l.

Tabel 1. Kisaran parameter kualitas air selama penelitian

\begin{tabular}{lccccc}
\hline \multicolumn{1}{c}{ Parameter } & \multirow{2}{*}{ Optimal } & \multicolumn{4}{c}{ Perlakuan } \\
\hline Suhu $\left({ }^{\circ} \mathrm{C}\right)$ & $25-29$ & $27.8-29$ & $27.8-28.7$ & $27.8-28.6$ & Boyd, 1991 \\
pH & $6-9$ & $7.5-7.9$ & $7.5-7.9$ & $7.6-7.8$ & Wedemeyer, 1996 \\
DO (mg/l) & $>4,>3$ & $4.9-5.9$ & $5.0-6.2$ & $5.1-5.9$ & Boyd, 1991 \\
Salinitas (ppt) & $30-35$ & $33-35$ & $33-35$ & $33-35$ & Boyd, 1991 \\
\hline
\end{tabular}


Berdasarkan hasil pengamatan suhu pada wadah pemeliharaan yangmenggunakan multi layer filter diperoleh masih dalam nilai optimal untuk pertumbuhan dan kelangsungan hidup ikan banggai kardinal. Hal ini sesuai dengan pernyataan Brotowidjoyo (1995) bahwa kisaran suhu yang baik untuk budidaya adalah antara $20-30^{\circ} \mathrm{C}$. Hal yang sama pula direkomendasikan oleh Boyd (1991) bahwa suhu yang baik untuk pemeliharaan ikan yaitu antara 25 - 290C. Hasil pengukuran salinitas rata-rata selama masa pemeliharaan berkisar antara 33-39 ppt, kisaran salinitas tersebut masih dalam batas optimal. Menurut Fujaya (2008), kisaran salinitas untuk melakukan kegiatan budidaya berkisar 24-40 ppt, untuk itu khususnya dalam budidaya ikan banggai cardinal mampu bertahan hidup pada salinitas yang tinggi dan Menurut Boyd (1991) ikan hias air laut memiliki salinitas optimum yaitu pada salinitas 30-35 ppt. Demikian juga dengan kisaran $\mathrm{pH}$ pada penelitian ini yang masih dalam batas toleransi untuk pertumbuhan dan kelangsungan hidup ikan Banggai Cardinal. Kondisi ini sesuai dengan pernyataan Boyd (1991), bahwa air normal yang memenuhi syarat untuk kehidupan organisme perairan mempunyai $\mathrm{pH}$ berkisar antara 6-9. Sedangkan nilai oksigen terlarut yang terukur adalah 4,9-6,2 didukung oleh Boyd (1991) merekomendasikan nilai DO yang baik untuk kepentingan budidaya ikan yaitu $>4$ ppm sedangkan Wedemeyer (1996) menyatakan bahwa nilai DO $>3$ ppm baik untuk pertumbuhan dan kelangsungan hidup ikan yang dibudidaya. Bila dilihat nilai DO yang diperoleh selama penelitian maka dapat dikatakan bahwa layak untuk menunjang pertumbuhan dan kelangsungan hidup ikan uji.

\section{Kelulusan Hidup}

Salah satu faktor penting dalam kegiatan budidaya adalah sintasan atau kelangsungan hidup. Kelangsungan hidup atau yang biasa disebut dengan nama lain yaitu sintasan merupakan sejumlah organisme yang hidup pada akhir pemeliharaan yang dinyatakan dalam persentase. Berikut hasil sintasan pada pada pemeliharaan Ikan Banggai Cardinal (P. kauderni) menggunakan variasi sistem multi layer filter selama waktu penelitian dicantumkan dalam bentuk grafik pada Gambar 4. Selama periode pemeliharaan ikan banggai cardinal menunjukkan bahwa persentase sintasan tertinggi pada akhir penelitan diwakili oleh perlakuan B yaitu 66,67\%. Sitasan atau kelangsungan hidup akan tinggi jika faktor kualitas dan kuantitas pakan serta kualitas lingkungan mendukung. Faktor-faktor yang mempengaruhi tingkat kelangsungan hidup suatu organisme antara lain adalah kualitas air, padat penebaran, nutrisi dan kemampuan adaptasi terhadap lingkungan. 


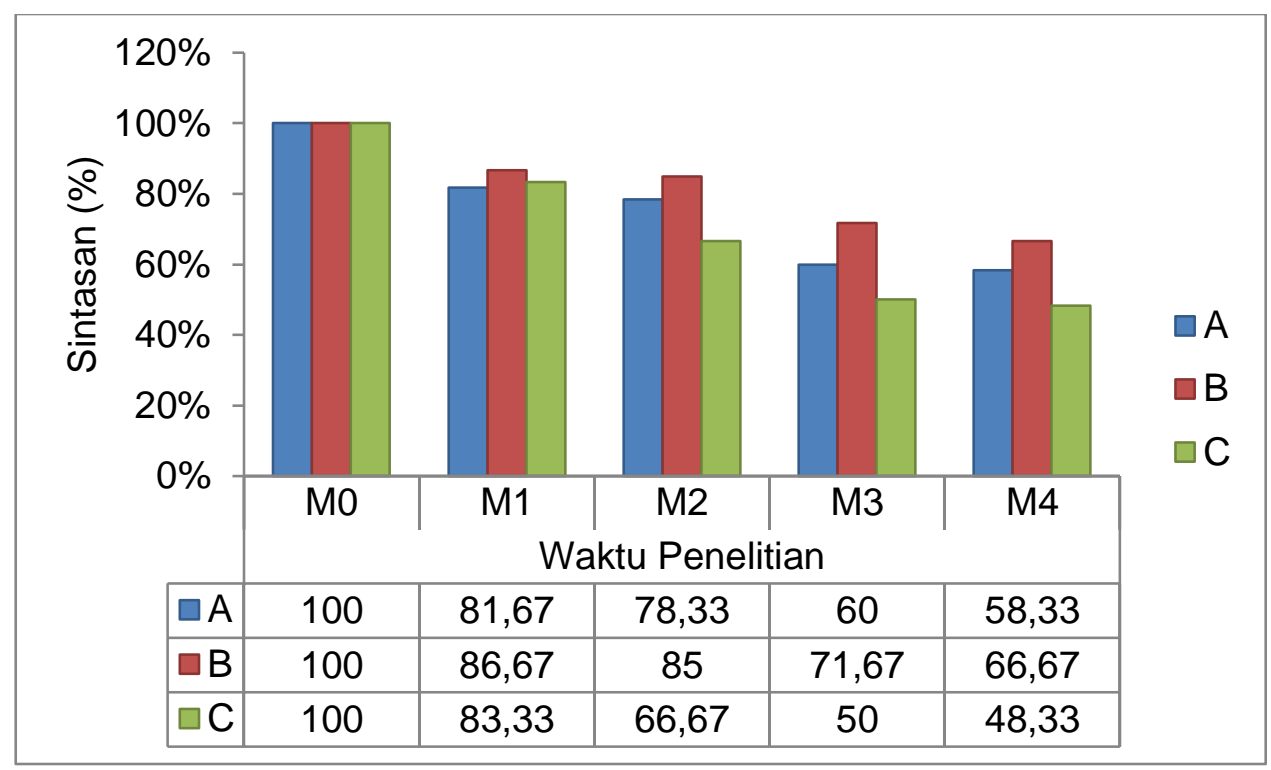

Gambar 4. Kelulusan Hidup Ikan banggai cardinal selama pemeliharaan

\section{KESIMPULAN}

Variasi komponen sistem resirkulasi multi layer filter dengan komposisi bioball, arang aktif, dakron, dan pasir (Perlakuan B) pada pemeliharaan ikan banggai cardinal (P. kauderni) merupakan perlakuan terbaik dalam mereduksi konsentrasi amonia hingga 0.3 mg/l hingga akhir penelitian sehingga dapat meningkatkan kualitas air media pemeliharaan. Penerapan variasi sistem resirkulasi multi layer filter pada pemeliharaan ikan banggai cardinal (P. kauderni) memberikan pengaruh yang lebih baik terhadap kualitas air sehingga pada perlakuan B mampu meningkatkan kelangsungan hidup berkisar antara $66,67 \%$.

\section{DAFTAR PUSTAKA}

Boyd, C.E. (1982). Water quality management for pond fish culture. Amsterdam : Elsevier Scientific Publ. Co Montoya dan Velasco, 2000

Boyd, C.E. 1990. Water quality in found Aquaculture. Birminghann Publishing : Alama

Cahyo. (2011). Bioball chemical Indonesia. Di akses pada tanggal 24 Maret 2019 pukul 19:38. Bioball.blog.com.2011/03/05/bioball

Djokosetiyanto, D., Sunarma, A., \& Widanarni. (2006). Perubahan Ammonia (NH3-N), Nitrit (NO2-N) dan Nitrat (NO3-N) pada Media Pemeliharaan Ikan Nila Merah (Oreochromis sp) di dalam Sistem Resirkulasi. Jurnal Akuakultur Indonesia, 5, 13-20. Duborow, R.M., Crosby, D.M., \& Brunson, M.W. (1997). Ammonia in Fish Pond. Southern Regional Aquaculture Center. SRAC Publ. No. 463

Effendie, M. I. (1997). Metode Biologi Perikanan. Cetakan Pertama. Yayasan Dewi Sri, Bogor, $112 \mathrm{hlm}$. 
Fauzzia, M., Izza, R., \& Nyoman, W. (2013).Penyisihan Amonia dan Kekeruhan pada Sistem Resirkulasi Budidaya Kepiting dengan Teknologi Membran Biolfiter. Jurnal Teknologi Kimia dan Industri, 2, 155-161.

Fujaya Y. (2008). Pengaruh spektrum cahaya terhadap perkembangan ovarium Kepiting Bakau (Scylla serrate Forskal) [Thesis]. Sekolah Pasca Sarjana IPB : Bogor.

Kordi, M. G. H. (2004). Penanggulangan Hama dan Penyakit Ikan. Rineka Cipta, Jakarta.

Prayogo, B,S,R., \& Abdul, M. (2012). Eksploritasi Bakteri Indigen pada Pembenihan Ikan Lele Dumbo (Clarias sp.) Sistem Resirkulasi Tertutup. Jurnal Ilmiah Perikanan dan Kelautan, 4, 193-197.

Ristiana, N., Astuti, D., \& Kurniawan, T.P. (2009). Keefektifan Ketebalan Kombinasi Zeolit dengan Arang Aktif dalam Menurunkan Kadar Kesadahan Air Sumur di Karangtengah Weru Kabupaten Sukoharjo. Jurnal Kesehatan, 2, 91-102

Sahetapy, J.M.F., Louhenapessy, D.G., \& Riry, E. (2016). The Impact of component Modification of Double Bottom Filter Recirculation System to concentration of Ammonia in water and survival rate at rearing media of Blue Devil Fish (Chrysiptera cyanea). Akuakultura Indonesiana, 17(1), 26-29

Sidik, A.S. (2002). Pengaruh Padat Penebaran Terhadap Laju Nitrifikasi dalam Budidaya Ikan Sistem Resirkulasi Tertutup. Jurnal Akuakultur Indonesia, 1, 47-51

Wedemeyer. (1996). Growth and Ecology of Fish Populations. Academic Press : London 